\title{
Quem precisa de Direitos? 0 fenômeno violência em contraposição aos direitos e à moralidade cristã
}

\author{
Who needs rigths? The violence in opposition to \\ fundamental rights and Christian morality
}

\section{Gleyds Silva Domingues, Ana Carolina Silva Domingues*}

[a] Faculdades Batista do Paraná, (FABAPAR), Curitiba, PR, Brasil

[b] Universidade Federal do Paraná, (UFPR), Curitiba, PR, Brasil

\section{Resumo}

A proposta deste artigo é analisar o fenômeno violência em contraposição aos direitos fundamentais e à moralidade cristã. Para tal finalidade busca-se compreender a forma como este fenômeno se evidencia na realidade social, na tentativa de sinalizar sobre o grau de impacto que exerce nas relações humanas, na medida em que os direitos e a moralidade são violados. Em relação aos direitos, observa seu impacto no ato de transgressão do que é mais valioso ao ser humano, a dignidade e a vida. Na moralidade cristã, o que se busca é ressaltar que a prática da violência causa estranhamento por

* GSD: Pós Doutora em Educação e Religião, e-mail: gleyds@ftbp.com.br ACSD: Mestranda em Direito, e-mail: dominguesanac@gmail.com 
se distanciar de normas sociais que regem o comportamento e que são aceitas e legitimadas no âmbito da cultura. Compreende-se que a violência é um fato social complexo e polissêmico e, por isso, exige certo grau de interpretação quanto ao seu alcance e presença. 0 artigo elege como problemática a seguinte questão: em que medida o fenômeno violência ao infringir os direitos fundamentais e a moralidade cristã continuam sendo acomodados e maximizados na realidade social, sem que ocorra uma reeducação do ser humano biopsicossocial e espiritual? Neste sentido, o entendimento a ser construído sustenta-se nos estudos de teóricos sobre o fenômeno da violência, dos direitos e da moralidade. 0 método de pesquisa adotado é o da análise do discurso por contemplar os processos de significação que são impressos nos discursos defendidos. Não se quer apresentar um estudo finalístico sobre o fenômeno, mas contribuir com as investigações nesta área, reconhecendo que pela natureza interdisciplinar impressa neste artigo, o esforço e o desafio são ainda maiores.

Palavras-chave: Violência(s). Direitos Fundamentais. Moralidade Cristã.

\section{Abstract}

The purpose of this paper is to analyze violence in opposition to fundamental rights and Christian morality. To such end, it intends to comprehend the way this phenomenon takes place in social reality, in an attempt to signal the degree of impact it exerts on human relation, as rights and morality are violated. In relation to rights, I observe their impact on the act of transgression of what is most valuable to the human being: dignity and life. Through the lens of Christian morality, what is sought is to emphasize that the practice of violence causes estrangement because it distances itself from the social norms that condition behavior, and that are accepted and legitimized culturally. Violence is portrayed as a complex and polysemous social fact, and as such demands a certain degree of interpretation as for its reach and presence. This paper is derived from the following question: how violence - as it infringes fundamental rights and Christian morality - continues to be accommodated and maximized in social reality, without the occurrence of a reeducation of this biological (psychological/spiritual) human beign? In this sense, the understanding to be built is sustained on theorists' studies on violence, rights, and morality. The research method is the discourse analysis as it contemplates the signification processes that are imprinted on defended discourses. 
I do not intend to present a finalistic study of the phenomenon, but to contribute with the literature, recognizing that because of the interdisciplinary nature of this work, effort and the challenge are even greater.

Keywords: Violence(s). Fundamental Rights. Christian Morality.

\section{Introdução}

Estudar o fenômeno da violência é percorrer a história da humanidade, no sentido de compreender como, no decurso de sua evolução, a sociedade enfrentou e vem enfrentando este problema social. Afinal, não se pode restringir este fenômeno somente ao ato material da agressão sofrida. Este envolve muito mais que uma ameaça ao direito de ser humano, visto que está entranhado por distanciamentos sobre o sentido de alteridade, constituindo-se, antes, na prerrogativa de um poder exercido sobre o outro. Seja este poder instrumentalizado ou simbólico, o certo é que o mesmo se concretiza nas relações sociais estabelecidas.

É preciso, ainda, perceber que na presença da prática da violência(s) são instituídos mecanismos de segurança/inibidores, que tentam ora assegurar ou suspender direitos, enquanto uma faculdade dos sujeitos de agir sobre a realidade. A questão que precisa ser ressaltada é que o ato de constituição dos direitos deve objetivar a busca da paz e da coexistência social. Afinal, não se pode vislumbrar os direitos como uma prerrogativa apenas correcional de um instituto legal, mas de uma necessidade advinda da própria sociedade para fazer valer acordos, contratos, regras, procedimentos, direitos e deveres, que visem produzir ou provocar o equilíbrio moral e justo nas práticas de convivência e existência sociais.

Interessante que o fazer direito também pode ser considerado como um fato social, o qual demanda a necessidade de estabelecer padrões de justiça a serem contemplados e até mesmo respeitados a partir da imposição de normas implicadoras da luta e da conquista pelo direito, por meio da prevenção, composição e resolução de conflitos, cuja decisão pode vir a ser materializada por intermédio de uma sanção, na medida em 
que restringe o desejo do fazer por uma medida a ser aplicada quando não há observância legal da norma imposta.

Quando se fala do fenômeno violência(s), vislumbra-se, logo de antemão, a não subserviência de uma norma padrão, a qual resulta na ilicitude do ato e por conta disso pode trazer o desequilíbrio, no tocante às regras que conformam a convivência entre homens e mulheres. Tanto é assim, que sua prática reserva em si a ausência de limites e regras. Há, sim, uma negação do que se legitima como postulados do exercício da moral e justiça.

A análise do fenômeno da violência revela o alto grau de complexidade em que está envolvido, visto tratar-se de um fato concreto que desestabiliza a harmonia tão defendida pela sociedade, uma vez que atinge diferentes dimensões da vida. Não é por acaso que há uma concentração interdisciplinar de pesquisadores e estudiosos advindos das áreas da filosofia, da saúde, do direito, da educação, da teologia, da antropologia, dentre outras, no sentido de debruçar sobre este objeto. Pensa-se na cooperação e no diálogo a ser construído, com vistas a encontrar possibilidades de ação socioeducativas que de modo efetivo e que vise minimizar os danos provocados.

Elege-se como finalidade deste artigo analisar o fenômeno da violência enquanto uma prática que se distancia dos direitos humanos e da moralidade cristã, o que evoca a necessidade de olhar para este fenômeno com cuidado, visto que sua ação informa sobre o não reconhecimento de um outro, conceito de desvalor. Além do distanciamento evidenciado, é preciso ainda, reconhecer uma área de tensão conceitual entre direito e moral, sendo esta área movediça, visto a discordância gerada entre os teóricos do Direito ${ }^{1}$. Isso porque, para alguns deles, como $\mathrm{Alexy}^{2}$, não

1 Palombella, em sua obra "La autoridad de los derechos: Ios derechos entre instituciones y normas" (2006, p. 71-72) revela que existem tensões no tocante às teorias que tratam da relação entre moral, ética e direito. Ele reporta que há teóricos que sustentam que a moral dá legitimidade ao direito, como o faz Dworkin, bem como aqueles que entendem que os valores morais até podem ser positivados, mas não conferem legitimidade ao direito, já que o reconhecimento das normas, ao menos pelos funcionários, conferiria sua legitimidade e obrigatoriedade, como se vê em Hart. Esta tensão se reproduz ao se tratar dos direitos fundamentais e da autoridade de tais direitos, de forma que o autor os coloca como inseridos em uma "zona franca" entre ambos os campos (moral e jurídico) [Tradução nossa].

2 Alexy desenvolve um sistema que permite analisar as normas de acordo com sua qualidade moral. Nesse sistema, ele faz a diferenciação entre as normas injustas e as consideradas sanáveis (ALEXY, 2009).

Rev. Pistis Prax., Teol. Pastor., Curitiba, v. 10, n. 1, 59-77, jan./abr. 2018 
se pode pensar o direito sem a moralidade, enquanto para outros, como Kelsen ${ }^{3}$, essa relação não se estabelece em forma de codependência.

A intenção a ser expressa sinaliza para a compreensão do fenômeno violência, a partir de uma moral cristã e humanizadora do sentido de ser pessoa. Visão que se encontra ancorada nas perspectivas da teologia cristã e dos Direitos Humanos. Afinal, o sentido atribuído ao ser humano pode ser revelador para a construção de um conceito sobre dignidade, igualdade, liberdade, responsabilidade, alteridade a ser corporificado nos relacionamentos. Diante disto, o ensaio elege como problemática a seguinte questão: em que medida o fenômeno violência ao infringir os direitos fundamentais e a moralidade cristã continuam sendo acomodados e maximizados na realidade social, sem que ocorra uma reeducação deste ser humano biopsicossocial e espiritual?

A proposta, então, lança mão da metodologia da análise do discurso, por entender que a mesma se debruça sobre ideias, sentidos, significados, discursos e modos de pensar a realidade social, o que se verifica nas relações que os sujeitos tecem sobre o mundo onde se encontram mergulhados como protagonistas de uma história ou histórias significadas.

A análise do discurso situa seu olhar na prática da linguagem, pois nela homens e mulheres apresentam suas ideias e, ainda, revelam-se, mostram-se e significam por meio dos discursos travados. Ela firma-se como uma prática social munida de sentidos que, segundo Fairclough (2012), se inscreve na presença de três momentos da linguagem: identitário, relacional e ideacional. Esses três momentos se explicitam na forma como o discurso se apresenta, oferecendo subsídios para a realização e para construção discursiva.

Assim, espera-se com este artigo despertar o desejo de novas investigações em relação ao objeto violência(s), sendo essa uma tentativa de provocação e alerta para um fato social que se consolida na realidade da "cidade" e que por isso mesmo se torna alvo direto de reflexões. Assim, que comece a incursão sobre este fato social.

3 Kelsen objetivou tornar o Direito uma ciência. Para tanto, precisou separar as normas jurídicas da moralidade, psicologia, ciências sociais e outros ramos. A instrumentalização de tal ideia perpassou a criação de um sistema jurídico composto apenas por normas jurídicas, em que tanto seu fundamento de validade, como de existência são pautadas na norma fundamental, a qual dá margem para a hierarquia do sistema (KELSEN, 1998, p. VII-IX). 


\section{Violência, Violências: desvio ou ausência de moral}

O termo violência tem natureza polissêmica ${ }^{4}$, por isso se torna complexo apresentar uma definição de forma padrão e definitiva, porém faz-se necessário apresentar o sentido que se está atribuindo a este termo, uma vez que a compreensão do sentido lança possíveis caminhos de análise sobre o fenômeno a ser investigado. Nessa direção, lança-se mão da reflexão de Michel Misse (2006, p. 1), sobre o fenômeno violência. Nela, o autor já aponta o desafio de compreender o seu significado, ao dizer que:

A tal da violência que parece agir como um espectro ou fantasma, esconde-se ou dissemina-se, é tratada como uma epidemia, um vírus, um micróbio, ou como um Sujeito onipresente, onisciente, onipotente. Que diabo é esse? O que unifica nesse nome conflitos, crimes e comportamentos tão diferentes? O que nos faz pensar que tudo isso tem um nome só?

A palavra violência do ponto de vista de sua origem deriva-se do latim violentia, associado a vis, cujo significado remete ao caráter de alguém violento e que usa a força física ou seu vigor contra um outro. Ainda acerca da palavra é possível associar os significados de quantidade, abundância, potência, energia e força em ação. O que enfatiza ainda mais a ideia de uma ação de força contra algo ou alguém.

Quando se deseja tratar da violência, enquanto um fato social, torna-se indispensável apresentar o seu conceito, visto que por seu intermédio são estabelecidas as fronteiras sobre a mesma. Diante disso e com a ajuda de Hannah Arendt, é possível dizer que a violência pode ser considerada sob a perspectiva da instrumentalidade, a qual lança mão de meios na concretização de seus atos e efeitos. O que implica em dizer que "a própria substância da violência é regida pela categoria meio/objetivo

4 Orlandi sobre a questão da polissemia, ressalta que ela é a fonte da linguagem, uma vez que por sua natureza múltipla possibilita a existência do espaço do dizer, ou seja, dos discursos. E se assim o é, pode-se verificar a multiplicidade de significados gerados a partir de um vocábulo empregado. Tanto que o vocábulo violência não se limita apenas ao campo material, mas engloba o campo simbólico e afetivo. Reitera-se que a polissemia de significados é real, uma vez que 0 ato gerador do sentido atribuído à palavra, nem sempre pode ser restrito a um sentido, antes sua significação ocorre no contexto real e é nele que os sentidos são reconhecidos, apropriados, legitimados e materializados na realidade social (ORLANDI, 2003, p. 18).

Rev. Pistis Prax., Teol. Pastor., Curitiba, v. 10, n. 1, 59-77, jan./abr. 2018 
cuja mais importante característica, se aplicada às atividades humanas, foi sempre a de que os fins correm perigo de serem dominados pelos meios" (ARENDT, 1970, p. 4). Assim, "a violência é por natureza instrumental; como todos os meios ela sempre depende da orientação e da justificação pelo fim que almeja" (ARENDT, 1970, p. 40-41).

Isso implica em pensar no fenômeno da violência como um fato impregnado de intencionalidade, o que retira, exclusivamente, o seu caráter involuntário que muitas vezes é invocado na prática de violência cometida. Afinal, a violência é proveniente da violação de um direito. Essa violação produz consequências na forma como se evidencia na vida quer do infrator como do lesado. De tal modo, pode-se dizer que "as violações dos direitos provêm de que todo detentor de poder está tentando dele abusar" (MORANGE, 2004, p. 31). Há, portanto, sinalizado que o ato de violência pode se originar na esteira do poder e, ainda, que "a violência abriga em seu seio um elemento adicional de arbitrariedade” (ARENDT, 1970, p. 5).

Surge neste contexto da prática da violência um novo elemento a ela vinculado, o poder. A partir deste novo elemento, pode-se entender que o ato de violência também pode ser principiado no contexto e na presença de um poder, quer seja real ou simbólico. O primeiro indica um instituto de autoridade conferido legitimamente, como o é no caso do Estado e o segundo sinaliza para um estado de força exercido por intermédio de uma prática da linguagem corporal, imagética ou emocional. A partir dessa ótica, a violência pode ser pensada como uma deturpação do uso do bom senso. Segundo Arendt (1970, p. 7), esse poder seria "o nosso órgão mental que se destina a perceber, compreender e lidar com a realidade e com os fatos", incluindo a capacidade de agir de maneira consciente, racional e ética. $\mathrm{Na}$ esteira do pensamento de Arendt, é possível concluir que o bom senso pode ser equiparado a um sensor que informa sobre as ações e ou reações de seus agentes.

Não se tem a pretensão aqui de discutir sobre o fenômeno da violência emanado do Estado, mas aquele que é advindo das relações sociais, uma vez que a proposta a ser configurada persegue a ideia de deslocamento, desvirtuamento de sentido sobre o outro. É esse distanciamento que se torna o objeto a ser investigado por estar destituído de um exercício cidadão, o qual deveria ancorar os valores de respeito, autonomia e bem 
comum. Exercício esse que promove o sentido de ser, existir, estar e agir em comunidade, ou seja, o exercício da prática usual do bom senso.

É na esteira da violência, enquanto fenômeno social, que se pode perceber diferentes iniciativas da sociedade, não apenas para compreender sua ação, mas a forma como ela se reveste de um poder sobre um outro ser humano. Tanto é assim, que a Organização Mundial da Saúde (OMS), classifica o fenômeno da violência em três tipologias: violência coletiva, violência auto infligida e violência interpessoal. A prática efetivada pela violência coletiva incide num cenário macrossocial, político e econômico, que é desferido pela dominação de grupos e do Estado. Deste modo, incluem-se "os crimes cometidos por grupos organizados, os atos terroristas, os crimes de multidões, as guerras e os processos de aniquilamento de determinados povos e nações" (OMS, 2002, p. 6).

Já a violência auto infligida diz respeito aos comportamentos considerados suicidas e de auto abuso, ou seja, são comportamentos infligidos contra a própria pessoa, o que pressupõe a existência de práticas de mutilação, negação e desvalorização quer atingindo o próprio corpo, quer atingindo sua identidade ou imagem pessoal, ou seja, são práticas atentatórias contra a própria dignidade da pessoa humana. Pode-se dizer que atentar contra a dignidade humana é o mesmo que violar os princípios da liberdade, justiça, solidariedade e moralidade.

A violência interpessoal é aquela que atinge o outro, o não eu, sendo infligida quer seja pelo parceiro ou não, isso envolve a ação praticada pelo "parceiro íntimo, o abuso infantil e abuso contra idosos" (OMS, 2014, Resumo executivo, p. VII). Esse tipo de violência é uma das marcas de prática desumana, que atenta contra os direitos de um outro, incluindo o direito à vida, à honra, à identidade e à dignidade humana.

Observa-se que estes tipos de violência são direcionados a um ente específico, quer seja à coletividade, à individualidade ou à alteridade. Isso demonstra que o nível de concretização da violência não é único, mas diverso, sendo muito difícil determinar uma única forma de ação infligida, o que requer a compreensão de caso a caso. Pode-se dizer que: 
[...] a violência configura-se como um dispositivo de controle, aberto e contínuo. A violência seria a relação social, caracterizada pelo uso real ou virtual da força ou da coerção. A violência seria a relação social de excesso de poder que impede o reconhecimento do outro - pessoa, classe, gênero ou raça, provocando algum tipo de dano, configurando o oposto das possibilidades da sociedade democrática contemporânea (SANTOS, 2009, p. 46).

Conceitua-se, assim, violência como "ações humanas de indivíduos e grupos, classes, nações que ocasionam a morte de outros seres humanos ou que afetam a sua integridade física, moral, mental ou espiritual" (MINAYO; SOUZA, 1998, p. 514). Este conceito traduz não apenas o sentido de ser da violência, mas as consequências que são desencadeadas por sua prática e que envolvem aspectos materiais e emocionais, o que implica em pensar em duas esferas de concretização da violência: física e simbólica. Na esfera física concentra-se o uso da força física sobre um outro ser. Já na esfera simbólica são utilizados meios de coação emocional e psicológica, por isso sua ação é lenta e de difícil identificação.

Além da forma física e simbólica de concretização da violência é preciso pensar no sentimento de medo desencadeado pela ausência de segurança, pelo caos estabelecido e pela impunidade diante de normas infringidas. Esse sentimento é avaliado assim:

O sentimento da insegurança, que se encontra no coração das discussões sobre o aumento da violência, raramente repousa sobre a experiência direta da violência. Ele corresponde à crença, fundada ou não, de que tudo pode acontecer, de que devemos esperar tudo, ou ainda de que não podemos ter certeza de nada nos comportamentos cotidianos. Aqui, novamente, imprevisibilidade, caos e violência estão juntos (MICHAUD, 1989, p. 13).

$\mathrm{O}$ ato de concretização da violência manifesta-se, então, por uma prática humana efetivada, que diz respeito ao não reconhecimento da presença do não eu, e não somente isso, mas uma ação que fragiliza, imobiliza e afeta direta ou indiretamente a integridade da pessoa, ou seja, a sua dignidade. Afinal, "o contrário da violência não é a não violência, é a cidadania e a valorização da vida humana por geral e de cada indivíduo no contexto de seu grupo" (COELHO; SILVA; LINDNER, 2014, p. 528). 
Se o contrário da violência é a cidadania e a valorização da vida humana, então algumas questões devem ser apresentadas como: será que o fenômeno violência ao violar os direitos da pessoa humana não está ao mesmo tempo agredindo à sua moralidade? Em que medida o direito no enfrentamento do fenômeno da violência se constitui na perspectiva da moral? Seria possível pensar na aplicação do Direito para atos de violência distanciados da moralidade?

Essas questões demandam um esforço reflexivo, porque não envolvem apenas um aspecto da problemática, antes se torna determinante para compreender o fenômeno, no sentido de sinalizar sobre possíveis formas de ação e tratamento que possam redundar numa prática socializante e reeducadora das condutas humanas. Aspectos que serão melhor elucidados no tema a seguir.

\section{Direito e a Perspectiva da Moralidade Cristã}

Ao tentar evidenciar a relação de cumplicidade entre o Direito e a sociedade, utiliza-se da frase de Dante Alighieri, em sua obra clássica "Monarquia", por evidenciar essa estreita dependência. Assim, ele expressa no segundo livro desta obra, capítulo V, que "O Direito é uma proporção real e pessoal, de homem para homem, que conservada, conserva a sociedade: corrompida, corrompe-a" (ALIGHIERI, 1992, p. 37). Esse olhar do dramaturgo revela a presença de uma correspondência entre normas, relações e condutas a serem mantidas e acordadas pelos seres humanos em prol de sua coexistência na sociedade. Isso indica que a partir desta ótica, o Direito não se distancia da moral, uma vez que assume como prerrogativa o bem-estar da sociedade na luta pela justiça e pela paz social.

Quando se fala em direito é preciso ter em mente as diferentes acepções atribuídas a este termo. E uma delas está diretamente associada a presença de normas ou regras de conduta. Isso ocorre porque,

A nossa vida se desenvolve em um mundo de normas. Acreditamos que somos livres, mas na realidade, estamos envoltos em uma rede muito espessa de regras de conduta que, desde o nascimento até a morte, dirigem nesta ou naquela direção as nossas ações (BOBBIO, 2016, p. 5). 
É claro que não se pode desconsiderar que muitas destas ações são frutos da escolha do ser humano, ou seja, em observar ou não as normas. Assim frente a escolhas pode-se vislumbrar ou não o desencadeamento de problemas, tais como o fenômeno violência, o que induz a pensar sobre o fator ou fatores que favorecem ou não a observância de uma norma de conduta.

Pensa-se na norma de conduta como uma prática consensual, em que é regida pelo viver bem em comunidade, embora há de se ressaltar que a norma de conduta traz em si mesma uma carga regulatória e previsível em forma de regras coercitivas e sanção. Assim sendo, pode-se inferir que esse viver bem é cerceado por ações valorativas de natureza moral. Para Reale (2014, p. 17), “o Direito corresponde à exigência essencial e indeclinável de uma convivência ordenada, pois nenhuma sociedade poderia subsistir sem um mínimo de ordem, de direção e solidariedade". $\mathrm{O}$ que indica que um dos fatores para que haja consenso na realidade social é aquele proveniente de uma perspectiva ética.

Não é de se estranhar que a base dos Direitos Humanos ${ }^{5}$ tem em sua essência a perspectiva da ética cristã 6 . Outro ponto a ser destacado é de que a visão cristã influenciou, sobremaneira, o Ocidente na adoção do conceito de ser humano. Isso porque,

[...] a convicção de que o homem foi criado à imagem de Deus e que ele foi salvo por Jesus Cristo enraizou solidamente na história da salvação a convicção da dignidade humana, o respeito do direito da pessoa humana ao livre desabrochar da solidariedade com outros homens (MORANGE, 2004, p. 55).

Este conceito de ser humano induz a pensar sobre a sua natureza formativa que está amalgamada com o próprio Criador. Sendo assim, por que seu comportamento não reflete a bondade e por que há desvirtuamento do seu caráter? Um possível argumento é o seu livre arbítrio, uma vez que a sua essência é de todo moral. Ainda sobre a questão do livre arbítrio, o Papa Leão XIII na Carta Encíclica Immortale Dei, posiciona-se da seguinte maneira:

5 Em relação à origem dos Direitos Humanos, Bobbio em sua obra "A era dos direitos" (1992, p. 57) ressalta que "teve início no Ocidente a partir da concepção cristã de vida, segundo a qual todos os homens são irmãos, enquanto filhos de Deus".

6 Embora existem linhas teóricas que não aceitam tal argumento, defendendo que a origem dos direitos humanos parte de uma prática histórica evolutiva. 
[...] se a inteligência adere às ideias falsas, e se a vontade escolhe o mal e se une a ele, nem uma nem outra alcançam a perfeição, ambas perdem sua dignidade inicial e se corrompem. Por isso não é permitido vir à luz e mostrar aos olhos dos homens o que é contrário à virtude e à verdade, e muito menos colocar isto sob a tutela da proteção das leis (Immortale Dei 38).

Sob este prisma, o ser humano, em prol de sua dignidade, deveria ser influenciado pela virtude e verdade, o que oportunizaria sua caminhada à perfeição, o que não pode ser tutelado pela lei, visto que a mesma também tem suas limitações. Assim, o campo da dignidade humana deve ser a busca constante do ser, viver e agir de cada ser humano, que à luz da verdade presente nas Escrituras compreende seu papel na história e na sociedade. Esse ser, viver e agir deve ser norteado pela moralidade cristã, a qual se fundamenta na perspectiva da revelação, classificada em dois momentos por Geisler (2010): geral e específico. O geral é destinado para todas as pessoas, pois contém os mandamentos de Deus e o específico explicita a vontade e o propósito de Deus em Cristo para aqueles que aceitam sua verdade. É, portanto, na essência da natureza reveladora de Deus que é possível encontrar o caráter moral de seus mandamentos e, isso indica que tanto a moral quanto a ética passam a ser entendidas no interior das condições históricas em que foi escrita e interpretada a revelação. A revelação e a história impulsionam a uma compreensão mútua e reflexão mútua do caráter santo, justo e bom de Deus, que se estende ao ser humano, criado à sua imagem e semelhança. E, ainda:

A partir da perspectiva da revelação tem-se o conhecimento sobre a natureza e o caráter daquele que se revela, ou seja, Deus. Esse, ato, portanto, oportuniza a tomada de consciência sobre sua essência e existência; e é nesse momento que se estabelece o conceito de alteridade, uma vez que não se tem um olhar limitado em si mesmo, o que sinaliza para a necessidade de uma prática moral de natureza relacional, que promova o sentido da convivência e respeito ao outro (DOMINGUES, 2017, p. 115).

Quando se deixa de lado a moralidade cristã, desconsidera-se os fundamentos da verdade e da virtude, instala-se a corrupção e, isso, nada mais é do que o afastamento dos princípios emanados pelo Criador. É na 
ausência dos princípios e da moralidade que surge a prática da violência ${ }^{7}$. De acordo com Candiotto (2011, p. 243), há que se ressaltar que mesmo diante da ausência da ética o "outro está presente em mim, eu não posso deixar de estar responsabilizado, pois até a indiferença já é uma resposta. As circunstâncias do outro me afetam, me interpelam e, principalmente, me responsabilizam". É por esse motivo que a atitude a ser assumida é de ordem educativa, o que é enfatizado pela declaração do Concilio Vaticano II, Dignitatis Humanae sobre a liberdade religiosa, que:

[...] exorta a todos, mas sobretudo aos que têm a seu cargo educar outros, a que se esforcem por formar homens que, fiéis à ordem moral, obedeçam à autoridade legítima e amem a autêntica liberdade; isto é, homens que julguem as coisas por si mesmos e à luz da verdade, procedam com sentido de responsabilidade, e aspirem a tudo o que é verdadeiro e justo, sempre prontos para colaborar com os demais (Dignitatis Humanae 8).

Um ponto a ser observado é que mesmo no interior da prática educativa não é negado ao sujeito a sua capacidade de agir com liberdade, porém, essa liberdade deve estar fundamentada na verdade e no exercício da moral. Ainda sob o aspecto da ação educadora, é preciso compreender que o que está em jogo é o princípio da dignidade ${ }^{8}$, na medida em que é ela "inerente a todos os membros da humanidade, funda seus direitos iguais e inalienáveis e garante a liberdade, a justiça e a paz no mundo. Essa dignidade advém da natureza mesma do ser humano e do fato de ser uma pessoa" (RICCI, 2012, p. 15).

A dignidade torna-se a marca da humanidade ${ }^{9}$ e, por isso, deve ser buscada, pleiteada e conquistada. Quando se trabalha no terreno da dignidade pode-se dizer que o desejo é de manter e fazer uma sociedade

7 Para Ricci (2012, p. 17) “não podemos cultivar uma liberdade viciada, como licença para fazer tudo, inclusive o mal, podendo cair no pecado. Proclama a vocação humana para a comunhão com Deus, cujo reconhecimento fundamenta e aperfeiçoa a própria dignidade humana". Ricci, assevera, ainda, que Jesus Cristo, o Filho de Deus, é o exemplo perfeito de dignidade, visto que revela plenamente Deus e realiza plenamente o humano.

8 Marcilio em Fundamentos Éticos dos Direitos Humanos (2012, p. 71) ressalta que "é justamente na dignidade humana que os fundamentos dos direitos humanos devem ser buscados. Tais direitos são universais, invioláveis e inalienáveis".

9 "A ideia da humanidade nos obriga a adotar aquela perspectiva do nós, a partir da qual nos consideramos uns aos outros como membros de uma comunidade inclusiva, que não exclui ninguém" (HABERMAS, 2010, p. 78).

Rev. Pistis Prax., Teol. Pastor., Curitiba, v. 10, n. 1, 59-77, jan./abr. 2018 
que se fundamenta nos princípios elementares do respeito, da liberdade, da solidariedade, da comunhão, da justiça e da paz. Por ser desejo, isso implica em dizer que sua concretização no plano real ainda é muito ideal, principalmente pelo apelo à noção de igualdade entre os homens. Habermas (2010, p. 78) assevera que "a universalidade das normas morais, que assegura a todos um tratamento igual, não pode permanecer abstrata; ela precisa permanecer sensível para levar em consideração as situações e os projetos individuais de vida de todos os indivíduos”.

Ainda sobre a dignidade, deve ser ressaltado que a prática da ética não pode ser autocentrada na pessoa, mas no espírito de coletividade, o que representa uma postura que contraria aos pressupostos da pósmodernidade, presentes no hedonismo e no individualismo exacerbado, o que contribui para acentuar a competitividade e o exercício do poder de um sobre o outro, trazendo desequilíbrio ao que se entende por bem comum.

Define-se bem comum como "o favorecimento do conjunto das condições sociais que permitem aos grupos sociais e às pessoas procurar atingir de forma mais completa possível a própria perfeição" (MARCILIO, 2012, p. 71). Para tal finalidade é preciso que se assegure os direitos fundamentais associados à alimentação, habitação, educação, saúde, cultura, informação, ao trabalho e ao transporte, além da liberdade e da igualdade de condições entre homens e mulheres.

Isso implica em dizer que o bem comum é um valor intrínseco ao viver em sociedade. Deste modo, cada cidadão deve cooperar para sua efetivação na realidade, visando que sua consolidação seja impressa por meio da ética e dos valores sociais. Para isso "é preciso denunciar circunstâncias que estão em contraste com a dignidade humana" (MARCILIO, 2012, p. 73). Dentre essas circunstâncias está a prática da violação dos direitos humanos, a qual é denegatória da moral e, assumida aqui como denegatória da moral cristã.

O bem comum, também, pode ser considerado como alvo da ação educativa que se inicia no contexto da família, sendo extensivo aos diferentes grupos sociais. Percebe-se, então, que a prática dos direitos humanos e da moralidade cristã se complementam na consecução deste objetivo, o que pode servir como ponto de partida para rever posicionamentos e comportamentos construídos socialmente. O certo é 
pensar que "a educação em direitos humanos não permite a passividade, mas propõe a indignação ante situações de injustiça, de arbitrariedade, de corrupção, de violências" (MARCILIO, 2012, p. 73-74). Não se pode ficar inerte a tal brutalidade e desumanização do ser humano, mas agir como portador de voz profética que anuncia e denuncia a barbárie.

\section{Considerações finais}

Discutir sobre o fenômeno da violência não é uma ação simples, mas nem por isso pode ser negligenciada, antes a atitude precisa ser de denúncia e anúncio a partir de uma postura educadora, que demanda reconhecer a complexidade e a pluralidade de perspectivas que se fazem presentes na realidade social para debater e refletir sobre este fenômeno. É preciso sentirse responsável e parte integrante do problema e da solução. Afinal, "enquanto nos compreendermos como pessoas morais, partiremos intuitivamente do fato que agimos e julgamos, in propria persona, de maneira insubstituível - de que nenhuma outra voz além da nossa própria nos fala" (HABERMAS, 2010, p. 80). Isso sinaliza que cada pessoa é responsável direta por suas ações, julgamentos e escolhas, porque a moral faz parte de sua essência e persona.

Uma das possibilidades de encarar o fenômeno da violência é aquela que parte da visão do direito e da moralidade cristã, na medida em que se apresenta com um olhar atento e responsivo à questão da dignidade humana, visto que a busca por uma sociedade justa deve ser encarada como parte de um desejo coletivo de concretização e acesso aos direitos fundamentais. Direitos esses que humanizam e possibilitam a convivência entre iguais e diferentes.

Por outro lado, reconhece-se que o fenômeno violência(s) contraria o sentido atribuído à dignidade humana, pois se existe a violação pelo ser humano de um direito, não se pode falar de respeito, solidariedade, igualdade, justiça ou sentimento de alteridade. A violação do direito avilta também a prática da moralidade cristã, por ser ela aquela que espelha a essência de um valor absoluto e universal, revelado pelo próprio Criador à criatura.

Longe de apresentar uma perspectiva puramente moralista, a intenção defendida caminha na esperança de que, a partir de uma perspectiva 
educadora, os direitos humanos sejam resgatados assim como a moralidade cristã, tão injustamente criticada e desprezada. Afinal, a máxima em que se funda sua razão de ser é no amar a Deus e ao próximo como a si mesmo, o que afasta das atitudes humanas ações que depreciam ou excluem o outro. Antes, a moralidade cristã ainda se posiciona com uma fé altruística.

A presença de uma fé altruística pode ser contemplada nos Evangelhos, a partir da vida e do exemplo do próprio Cristo, que em seus ensinos demonstra o valor dos relacionamentos pautados no amor, no respeito e na consciência do outro. São inúmeras as passagens bíblicas que revelam tal posicionamento. Dentre elas e a título de ilustração podem-se citar as bemaventuranças em Mt 5,3-11; o amor aos inimigos em Mt 5,43-48; o ato de não julgar ao próximo em Mt 7,1-6; Lc 6,37-38; 41-42; o maior mandamento em Mc 12,28-34; o ajudar o próximo — parábola do bom samaritano em Lc 10,28-37; o sentido de resplandecer e nutrir a luz em Lc 11,33-36; as consequências dos atos na prática de partilha em Lc 12,13-21; a comparação entre humildade e hospitalidade em Lc 14,7-14; a figura do bom pastor em Jo 10,11-16; a prática do lava pés em Jo 13,1-20, entre outras.

Ainda com relação à problemática levantada: em que medida o fenômeno violência ao infringir os direitos fundamentais e a moralidade cristã continuam sendo acomodados e maximizados na realidade social, sem que ocorra uma reeducação deste ser humano biopsicossocial e espiritual, pode-se inferir que sua ação é tão nociva quanto a incidência da prática da barbárie. Isso quer dizer que enquanto a sociedade sofrer com a violência, com a individualização narcisista, o processo de reeducação não se mostra como uma prioridade, o que incentiva ainda mais o grau de banalização da vida. Quanto mais a sociedade possibilitar ações educativas, mais perto se chegará do sentido do bem comum.

A atitude de olhar o outro não como oponente ou opositor, mas com o sentido de alteridade pode modificar a forma de convivência entre iguais e diferentes, sendo um passo para alcançar o tão idealizado bem comum. O sentido do bem comum já sinaliza para uma ação significada em comunidade, ou seja, na esteira da coletividade. O bem comum se materializa na prática efetiva da koinonia, que significa dividir o pão.

O que se pode dizer então? No exercício da voz profética é preciso declarar que o bem comum seja o alvo das práticas e ações sociais, pois se há 
o bem comum, com certeza haverá respeito e dignidade estendida a todos os seres humanos. O Apóstolo Paulo na Carta aos Filipenses 4,8 alerta: "Quanto ao mais, irmãos, tudo o que é verdadeiro, tudo o que é honesto, tudo o que é justo, tudo o que é puro, tudo o que é amável, tudo o que é de boa fama, se há alguma virtude, e se há algum louvor, nisso pensai”. O apóstolo, ainda, arremata sua reflexão de uma forma imperativa, ao dizer que aquilo recebido e aprendido por eles fosse colocado em prática, quer em palavras, quer em ações.

Sobre a ênfase atribuída pelo apóstolo Paulo à palavra e a ação é preciso destacar que a prática revela a tomada de decisão efetivada diante das circunstâncias da vida. A prática, ainda, demonstra o que de fato é prioridade nos relacionamentos. Assim, pode-se dizer que a prática constitui a palavra em movimento, ela é ação que dinamiza o sentir e o fazer presente nas relações humanas. Assim, quiçá seja essa a sua finalidade: buscar, significar e cultivar o bem comum em prol da convivência, da solidariedade e da paz entre os seres humanos.

\section{Referências}

ALEXY, R. Conceito e validade do direito. Trad. Gercélia Batista de Oliveira Mendes. São Paulo: WMF Martins Fontes, 2009.

ALIGHIERI, D. Monarquía. Madrid: Editorial Tecnos, 1992.

ARENDT, A. Da Violência (e-book). 1969/1970. Disponível em: <http://delubio. com.br/biblioteca/wp-content/uploads/2014/02/harendtdv.pdf $\rangle$. Acesso em: 15 jun. 2017.

BÍBLIA Sagrada: Nova Versão Internacional. São Paulo: Vida, 2000.

BÍBLIA Sagrada: Nova Versão na Linguagem de Hoje. Barueri: Sociedade Bíblica do Brasil, 1988.

BOBBIO, N. A Era dos Direitos. Rio de Janeiro: Campus, 1992.

BOBBIO, N. Teoria da Norma Jurídica. Bauru, SP: Edipro, 2016

CANDIOTTO, C. (org.). Ética: abordagens e perspectivas. Curitiba: Champagnat, 2011. 
COELHO; E. B. S; SILVA, A. C. G; LINDNER, S. R. Violências, definições e tipologias (e-book). Florianópolis: UFSC, 2014.

CONCÍLIO ECUMÊNICO VATICANO II, 1962-1965, Cidade do Vaticano. Declaração Dignitatis Humanae. Disponível em: <http://www.vatican.va/archive/ hist_councils/ii_vatican_council/documents/vat-ii_decl_19651207_dignitatis-humanae_po.html>. Acesso em: 18 de mai. 2017.

DOMINGUES, G. S. O espaço da ética significada no âmbito da cosmovisão cristã: uma questão de escolha. In: SOUZA, J. N. de; SOUZA, E. S. de. (orgs.). Teologia e Ética no Cuidado Pastoral. Curitiba: FABAPAR, 2017.

FAIRCLOUGH, N. Discurso e mudança social. São Paulo: Saraiva, 2012.

GEISLER, N. Ética Cristã: opções e questões contemporâneas. São Paulo: Vida Nova, 2010.

HABERMAS, J. O Futuro da Natureza Humana. São Paulo: Martins Fontes, 2010. KELSEN, H. Teoria Pura do Direito. 6. Ed. São Paulo: Martins Fontes, 1998.

LEÃO XIII. Carta Enciclica Immortale Dei. Sobre a Constituição dos Estados Cristãos. Roma, 1 de novembro de 1885. Disponível em: <https://w2.vatican.va/ content/leo-xiii/pt/encyclicals/documents/hf_l-xiii_enc_01111885_immortale-dei.html>. Acesso em: 18 mai. 2017.

MARCILIO, M. L. Fundamentos Éticos dos Direitos Humanos. In: SANTOS, I.; POZZOLI, L. Direitos Humanos e Fundamentais e Doutrina Social. São Paulo: Boreal Editora, 2012.

MICHAUD, Y. A Violência. São Paulo: Editora Ática, 1989.

MINAYO, M. C. S.; SOUZA, E. R. Violência e saúde como um campo interdisciplinar e de ação coletiva. Revista História, ciência, Saúde. Manguinhos, Rio de Janeiro, v. 4, n. 3, p. 513-531, nov. 1998.

MISSE, M. Crime e violência no Brasil contemporâneo. Rio de Janeiro: Editora Lúmen Júris, 2006.

MORANGE, J. Direitos Humanos e Liberdades Públicas. Barueri: Manole, 2004. 
ORGANIZAÇÃO MUNDIAL DA SAÚDE [OMS]. Relatório Mundial Sobre Violência e Saúde. Geneve: World Health Organization, 2002. p. 6

ORGANIZAÇÃO MUNDIAL DA SAÚDE (OMS). Disponível em: <http://www. paho.org/bra/> . Acesso em: 10 maio 2017.

ORGANIZAÇÃO DAS NAÇÕES UNIDAS (ONU). Declaração Universal dos Direitos humanos. EUA, 1948. Disponível em: <http://www.dhnet.org.br/direitos/deconu/textos/integra.htm>. Acesso em: 10 de mai. 2017.

ORLANDI, E. P. Análise do discurso: princípios e procedimentos. Campinas, SP: Pontes, 2003.

PALOMBELLA, G. La autoridad de los derechos: los derechos entre instituciones y normas. Madrid: Editorial Trotta, 2006.

REALE, M. Lições Preliminares do Direito. São Paulo: Saraiva, 2014.

RICCI, L. A. L. Afirmação Cristã da Dignidade Humana. In: SANTOS, I.; POZZOLI, L. Direitos Humanos e Fundamentais e Doutrina Social. São Paulo: Boreal Editora, 2012.

SANTOS, J. V. T. Violências e conflitualidades. Porto Alegre: Tomo Editorial, 2009.

Recebido: 27/07/2017

Received: 07/27/2017

Aprovado: 17/11/2017

Approved: 11/17/2017 